\title{
НОВАЯ СТРАНИЦА В ЛЕТОПИСИ ИСТОРИИ ВОЕННОЙ МЕДИЦИНЫ РОССИИ
}

История медицины давно уже стала одной из любимых областей научного творчества российских военных врачей, умевших сочетать свою служебную деятельность с серьезным занятием историей медицины. Такими были - один из основоположников истории медицины в России Я. А. Чистович, В. Я. Джунковский, В. В. Пашутин, Г. Г. Скориченко и авторы многочисленных очерков по истории кафедр Военно-медицинской академии, а в советское время стали Н. А. Богоявленский, В. Ф. Груздев, выдающийся отечественный историк медицины А. С. Георгиевский, В. И. и Е.Ф. Селивановы, В. И. Дедюлин и многие другие, чьи труды прочно вошли в свод отечественных историко-медицинских исследований.

В 90-х годах количество публикаций по истории военной медицины заметно уменьшилось. И вот неожданно в 1996 году в С. Петербурге выходит в свет “Вестник истории военной медицины” (в. I, 127 с.). Его выход знаменательное событие для всех отечественных историков медицины, так как являет собой пример энтузиазма и подлинного научного патриотизма, преодолевающего все трудности и препоны нашего современного бытия.

После краткого предисловия, подписанного профессором А. С. Георгиевским, следует обстоятельная статья начальника Военно-медицинского музея МО России В. С. Крутова, подводящая итоги более, чем 50-летнего изучения опыта медицинского обеспечения боевых действий Вооруженных Сил в годы второй мировой войны.

Уже краткое перечисление монографических работ и коллективных трудов, посвященных этой теме, свидетельствует о большой и плодотворной деятельности сотрудников Военно-медицинского музея в этом направлении. К сказанному нужно было бы добавить, что деятельность историков военной медицины, как, впрочем, и деятельность всех отечественных историков медицины, протекала далеко не в оптимальных условиях, и пресловутый “остаточный” принцип финансирования науки прежде всего сказывался, да и сейчас сказывается, на историках науки. 
И поэтому их труд - это не просто выполнение своего служебного долга, а подлинное служение науке.

За статьей В. С. Крутова следует краткое сообщение В. А. Егорова, рассказывающего о памятниках медикам Великой Отечественной войны, воздвигнутых на территории СНГ по данным на 1 января 1991 года. Содержание этой статьи носит большой эмоциональный заряд и за сухим перечнем памятников и памятных знаков, поставленных погибшим на войне врачам, фельдшерам и медицинским сестрам, зримо встаёт героический образ целого поколения медицинских работников, не щадивших своей жизни для защиты родины. И, конечно же, эта тема заслуживает более широкого освещения и раскрытия.

То же можно сказать и о статье В.П.Грицкевича "К вопросу о методологии истории медичины ". Тема, избранная для обсуждения, бесспорно важна, но так, как её представляет автор, она явно не умещается в рамках рецензируемого сборника. Обсуждение общефилософских проблем истории, "цены прогресса" науки и техники, критика борьбы материалистического и идеалистического направлений в науке - всё это проблемы для отдельных монографий и едва ли их можно не только уместить, но даже поставить рядом в небольшой статье сборника научных историко-медицинских работ.

Особого внимания заслуживает статья В. И. Селиванова и Е.Ф. Селиванова "О некоторых методологических вопросах экспозиций историкомедицинских музеев в свете современности". Нужно сказать, что медицинское музееведение - одна из мало освещенных проблем истории отечественной медицины и, хотя на территории бывшего Советского Союза сохранились сотни научных, учебных и мемориальных историкомедицинских музеев, серьезных работ, посвященных этой теме, еще нет, и авторы не пытаются ее решить в полном объёме. Статья посвящена только одному из её разделов - созданию историко-медицинских экспозиций. Основные положения, высказанные авторами, не могут вызывать возражений. Экспозиции музеев должны создаваться “... на подлинно научных началах, со строгим соблюдением принципа историзма, на основе изучения максимума источников, отражсаюиих истинную картину историко-медицинских событий, без допущения каких-либо отклонений ни в сторону бездумного восхваления, ни в сторону огульного очернительства проилого" (с. 23). Не подлежит также сомнению, что “отечественная медицина на всем протяжении своей истории развивалась 6 тесном единстве с мировой", как, впрочем, и вся наука, однако при этом всегда нужно помнить, что "наука не имеет родины, но ученые ее имеют" (Л. Пастер). Без этого невозможно создание ни мемориальных музеев, ни экспозиций, посвященных жизни и деятельности ученых. Очень важен вопрос об использовании в музеях аудиовизуальной и компьютерной техники. Это, конечно же, повышает эмоциональное воздействие на 
посетителей музея, однако при этом нужно иметь чувство меры, иначе музей, как справедливо пишут авторы статьи, может превратиться "из храма науки в некое 'иллюзионное шоу'”.

Ряд статей сборника посвящен Н. И. Пирогову. Открывается этот раздел статьей Ю. В. Саенко, В. И. Селиванова и Е. Ф. Селиванова - "Пути и перепутья отечественного пирогововедения". В этой статье много интересного, а иногда и дискуссионного, но самое важное, что авторам удалось ответить на вопрос, почему Николай Иванович Пирогов пользовался такой популярностью и признанием в самых широких кругах русской интеллигенции. В современном науковедении не редко можно встретить утверждение, что в научных биографиях ученый выступает в трех ипостасях: личностной (истории жизни), научной (что конкретно внёс ученый в развитие науки) и социально-политической. Но некоторые из великих предстают еще в одной ипостаси - моральнонравственной. В России она всегда занимала первое место, перекрывая все прочие: Н. И. Пирогов тому свидетельство. В советское время свет морально-этического образа Пирогова как-то потускнел, лучше сказать, его старались затушевать и отсюда, как бы в виде компенсации стремление, и часто неуклюжее, возвеличить его научные заслуги. Авторы справедливо критикуют эту тенденцию в изучении научного наследия великого ученого и в то же время подчеркивают его бесспорный приоритет в решении многих проблем теории и практики медицинской науки и, прежде всего, военной медицины.

Н.И.Пирогову посвящены также статьи А.И.Чалганова "Н. И. Пирогов как nатриот России", Г. Н. Куприященко "Н. И. Пирогов в художественной литературе", И.С.Захарова "Н. И. Пирогов и религия", В. А.Егорова "Памятники Н. Н. Пирогову".

Две статьи сборника посвящены С.П.Боткину. Это статья А.В.Шабунина "С. П. Боткин как человек и гражданин" и статья В.И. Дедюлина. Особо нужно остановиться на второй: под скромным названием "Памятные боткинские места в Петербурге" скрывается серьезное исследование об очень важном периоде в деятельности С. П. Боткина, целиком связанного с Петербургом. Автор скрупулёзно собрал сведения о всех зданиях, в которых работал или посещал в это время С. П. Боткин. Все приводимые данные хорошо документированы многочисленными сносками и послужат надежной основой для составления действительно научной биографии нашего выдаюшегося ученого и патриота С. П. Боткина.

Памяти И. П. Павлова посвящена статья К. А. Ланге "Первый российский лауреат Нобелевской премии". Автор приводит малоизвестные сведения из предистории присуждения Ивану Петровичу Павлову Нобелевской премии и подчеркивает непреходящую ценность трудов в области физиологии пищеварения, выполненных И. П. Павловым в стенах Института экспериментальной медицины. 
В статье В.С. Крутова и Ф.А. Иваньковича рассказывается о роли М. И. Голенищева-Кутузова в организации медицинского обеспечения войск действующей армии в Отечественную войну 1812 года. На основании значительных по своему объёму литературных и опубликованных архивных материалов, авторы показали постоянную заботу М. И. Кутузова о здоровье солдат и его внимание к организации медицинской помощи в действующей армии. Особенно подробно описано участие М. И. Кутузова в организации медицинской помощи раненым и больным воинам с августа 1812 г. по январь 1813 г., когда им было отдано более 30 различных приказов и распоряжений по этому поводу. Впервые в нашей литературе подчеркивается роль Я. В. Виллие, который пользовался у М. И. Кутузова полным доверием.

С. М. Левин посвятил свою статью деятельности Гаврилы Романовича Державина (бывшего с мая 1784 г. по ноябрь 1785 г. наместником Олонецкой губернии) по организации медицинской помощи населению на территории современной Карелии. Имя Г. Р. Державина хорошо известно как выдающегося русского поэта, и приведенные автором малоизвестные данные о его участии в строительстве больницы в Петрозаводске характеризуют его еще как гражданина и государственного деятеля, понимающего значение сохранения здоровья и оказания помощи больным в подведомственной ему губернии.

Несколько статей сборника посвящены вопросам из истории советской медицины. Сюда относятся стятьи: "История возникновения и разработки проблемы обитаемости объектов военной техники" В. Ф. Жернового и В. М. Горенкова, "К истории изучения отечественных лекарственных и ядовитых растений" С. Е. Шпиленя, "Из истории музыкотерапии" Л. А. Батуриной, “3. Г. Френкель и его труд 'Удлинение жизни и активная старость'" В. П. Романюка. Каждая из этих статьей открывает какуюто новую и малоизвестную пока нам страницу в истории отечественной медицины. Эти работы, весьма возможно, откроют новые направления в наших историко-медицинских исследованиях и опубликование их можно только приветствовать.

Конечно, далеко не все статьи, помещенные в сборнике, равноценны и оригинальны. Так, Н.М.Прыгова в сообщении "Земская медицина в начале $X X$ века" повторяет, уже в который раз, публикуемые в нашей печати рассказы о преследовании в России в начале XX столетия радикальной медицинской интеллигенции, которой, наверно, не снилось как с ней будут обращаться в конце этого века, а Р. В. Суворова, Г. Л. Микиртичан в статье "Клятва Гиппократа и современные проблемы биоэтики" с пафосом повествуют о морально-этическом значении клятвы Гиппократа, хотя ни у кого это не вызывало и, по всей видимости, не может вызывать возражений. 
Однако, несмотря на некоторые недостатки, по большей части редакционного характера, первый выпуск "Вестника истории военной медицины" бесспорно удался и его редколлегию и весь коллектив Военно-медицинского музея Министерства обороны Российской Федерации можно поздравить с большой творческой удачей - они сделали большое и важное дело, положив начало новому периодическому историко-медицинскому изданию, которому суждена большая и славная жизнь - в это мы твердо верим!

\section{A New Page in the History of Military Medicine in Russia (Summary) By Konstantin K. Vasilyev and Konstantin G. Vasilyev}

A review of a new periodical publication of the history of medicine, which had been issued in 1996 in St. Petersburg by the Ministry of Defense of the Russian Federation, the Museum of Military Medicine. That is a great event for all historians of medicine. The publication was made possible thanks to the enthusiasm of the Museum's coworkers and their scientific patriotism, by overcoming various every day obstacles. The review has analyzed several more important articles.

Константин Константинович Васильев, доктор медицинских наук, профессор А/Я 36, Сумы 35, 244035, Украина

Константин Георгиевич Васильев, доктор медицинских наук, профессор А/Я 202, Одесса 114, 270114, Украина 


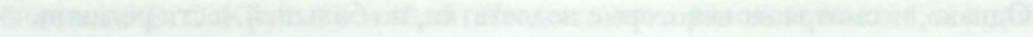

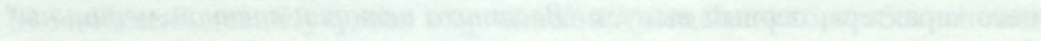

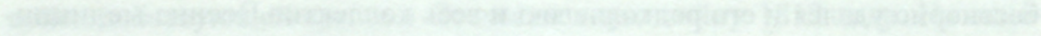

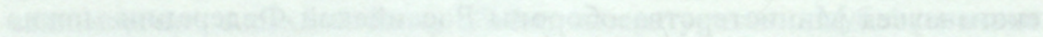

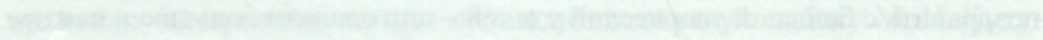

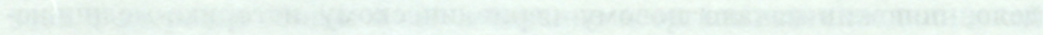
Whan

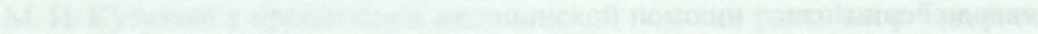

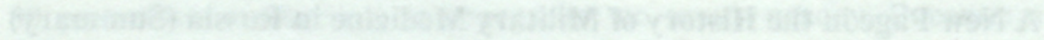

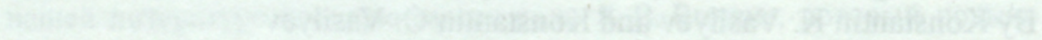

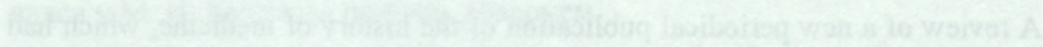

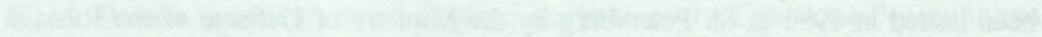

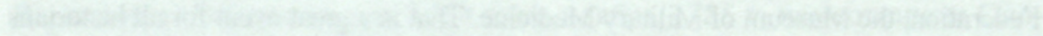

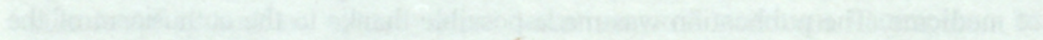

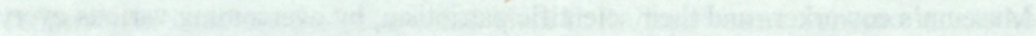
and

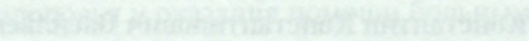

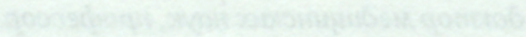

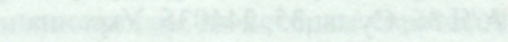

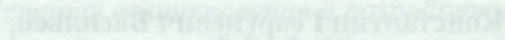

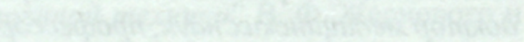

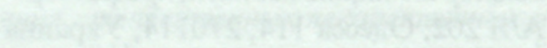

